DOI:http://dx.doi.org/10.18524/1810-4215.2019.32.181736

\title{
CHEMICAL IMPRINTS IN ATMOSPHERIC ABUNDANCES IN PLANET- HOSTING STARS
}

\author{
T. Mishenina, N. Basak, V. Kovtyukh \\ Astronomical Observatory, Odesa National University, Odesa, 65014, Ukraine, tmishenina@ukr.net
}

ABSTRACT. We examined 12 planet-hosting stars based on homogeneous spectral data (obtained with the SOPHIE echelle spectrograph with $\mathrm{R}=75,000$ at the OHP, France) and using uniform techniques for determination of parameters and abundances of a series of elements $(\mathrm{Li}, \mathrm{C}$, $\mathrm{Na}, \mathrm{Mg}, \mathrm{Al}, \mathrm{S}, \mathrm{Si}, \mathrm{K}, \mathrm{Ca}, \mathrm{Sc}, \mathrm{Ti}, \mathrm{V}, \mathrm{Cr}, \mathrm{Mn}, \mathrm{Fe}, \mathrm{Co}, \mathrm{Ni}, \mathrm{Zn}$, $\mathrm{Y}, \mathrm{Zr}, \mathrm{Ba}, \mathrm{La}, \mathrm{Ce}, \mathrm{Pr}, \mathrm{Nd}, \mathrm{Sm}$ and $\mathrm{Eu})$.

For our set of stars with detected massive planets, we have found $[\mathrm{Fe} / \mathrm{H}]$ ranging from --0.3 to 0.4 dex. There is the only star for which the lithium content has been reliably shown to be lower than predicted values. Average $\mathrm{C} / \mathrm{O}$ ratio $(0.52 \pm 0.08)$ is slightly lower than the solar one (0.54), and $\mathrm{C} / \mathrm{O}$ ratios tend to correlate with the planetary mass. Magnesium follows the trend in Galactic chemical evolution exhibiting a dependence on the planetary mass. Manganese and barium are both slightly overabundant.

Keywords: stars: abundances - stars: atmospheres - stars: planetary systems - techniques: spectroscopic

АНОТАЦІЯ. Ми дослідили 12 зір 3 планетами, спираючись на однорідні спектральні дані (отримані на ешель спектрографі SOPHIE 3 роздільною здатністю $\mathrm{R}=75000$ в Обсерваторії От Прованс, Франція) та використовуючи єдині методики визначення параметрів й вмісту ряду елементів $(\mathrm{Li}, \mathrm{C}$, $\mathrm{Na}, \mathrm{Mg}, \mathrm{Al}, \mathrm{S}, \mathrm{Si}, \mathrm{K}, \mathrm{Ca}, \mathrm{Sc}, \mathrm{Ti}, \mathrm{V}, \mathrm{Cr}, \mathrm{Mn}, \mathrm{Fe}, \mathrm{Co}, \mathrm{Ni}$, $\mathrm{Zn}, \mathrm{Y}, \mathrm{Zr}, \mathrm{Ba}, \mathrm{La}, \mathrm{Ce}, \mathrm{Pr}, \mathrm{Nd}, \mathrm{Sm}$ та Eu).

Важливу роль відіграє вивчення хімічного складу материнських зірок, які в хімічному складі атмосфери можуть нести «відбитки» присутності планетарних систем, а співвідношення елементів є важливими для вивчення утворення планет різних мас.

Наші досліджувані зірки 3 масивними планетами мають різну металічність $-0.3<[\mathrm{Fe} / \mathrm{H}]<0.4$. Отже, суперметалічність не може бути надійним критерієм наявності планет. Різний вміст літію в наших цільових зірках відповідає еволюційним змінам. Лише одна зірка (HD13908, вік 2.9 Гр) показує виснаження літію порівняно 3 прогнозом еволюції. Наші середні значення $[\mathrm{C} / \mathrm{O}]=-0.03 \pm 0.07$ й $\mathrm{C} / \mathrm{O}=0.52 \pm 0.06$ не підтримують збагачення вуглецем в нашому зоряному зразку, але це узгоджується 3 результатами, отриманими Suarez-Anders ma iн. (2018). Ми спостерігаємо невеликий тренд $\mathrm{C} / \mathrm{O}$ з металічністю й масою планети. Середня величина $<[\mathrm{Mg} / \mathrm{Si}]>_{\mathrm{pl}}=-0.05$ $\pm 0,09$ нижче сонячної величини $[\mathrm{Mg} / \mathrm{Si}] \odot=0.0$, спостерігається тренд залежності $[\mathrm{Mg} / \mathrm{Si}]$ від маси планети. Марганець та барій виявляють деякий надлишок вмісту. Жодна 3 досліджуваних зірок не продемонструвала жодних значних нахилів (залежностей) відносного вмісту вогнетривких елементів до летких від температури конденсації $\mathrm{T}_{\text {cond. }}$

Ключові слова: зірки: вміст - зірки: атмосфери зірки: планетарні системи - методи: спектроскопічні.

\section{Introduction}

The study of stars with planetary systems is a rapidly developing branch of astrophysics. Most exoplanets were discovered by spectrometric measurements of the radial velocity of stars and planetary transits. Studying the chemical composition of parent stars plays an important role as chemical imprints in their atmospheric abundances may be used as indicators of the presence of planetary systems while elemental ratios are essential to study formation of planets of different masses.

The first studies revealed a relationship between metallicity $[\mathbf{F e} / \mathbf{H}]$ and the presence of planets (e.g. Gonzales 1997; Udry \& Santos 2007 and references therein), and subsequently it was shown that such a relationship could be observed in the stars with massive planets like Jupiter (e.g. Israelian \& Mayor 2001; Fischer \& Valenti 2005; Sousa et al. 2008). Later, suggestions were made to detect exoplanets in metal-poor stars (Sousa et al. 2008; Adibekyan et al. 2012b, a; 2015). Lithium $\left(\mathrm{Li}^{7}\right)$ deficiency has been associated with the presence of planets (Gonzalez \& Laws 2000; Gonzales et al. 2008, 2010; Israelian et al. 2004, 2009; Delgado Mena et al. 2014; Figueira et al. 2014; Mishenina et al. 2015, etc.) while an excess of lithium isotopes $\mathrm{Li}^{6}$ has been deemed to indicate the presence of massive planets (e.g. Israelian et al. 2001 Montalban \& Rebolo 2002). Delgado Mena et al. (2015) reported lower lithium content in the host stars of massive planets $(-0.14)$ as compared to the stars without detected planets. However, the rotational velocities $v_{\text {sini }}$ of stars with hot Jupiters tend to be higher on average than those of single stars suggesting that rotationally induced mixing (rather than the presence of planets) might be responsible for greater lithium depletion. A strong correlation between the lithium content and age was observed, which could be due to stellar evolution (Baumann et al. 2010; Carlos et al. 2016).

The carbon to oxygen ratios $\mathbf{C} / \mathbf{O}$ in planet-hosting stars can provide key information about the protoplanetary discs in which the relevant planets are formed (Kuchner \& Seager 2005). There are noticeable discrepancies in the estimates of $\mathrm{C}$ and $\mathrm{O}$ abundances in various studies to date. 
For instance, Petigura \& Marcy (2011) reported that planetbearing systems were enriched in carbon with $\mathrm{C} / \mathrm{O}>=1.00$; however, a number of other studies (e.g. Nissen et al. 2013, 2014) did not support the existence of carbon-rich planets with the $\mathrm{C} / \mathrm{O}$ values not exceeding 0.8 . Teske et al. (2014) found that the mean $\mathrm{C} / \mathrm{O}$ ratio for their sample of transiting exoplanet host star was $0.54\left(\mathrm{C} / \mathrm{O}_{\odot}=0.54\right)$ as compared to the previously measured $\mathrm{C} / \mathrm{O}$ averages for the host stars of 0.65-0.75. Later, Suárez-Andrés et al. (2016, 2017) showed that the linear relationship between $[\mathrm{N} / \mathrm{Fe}]$ and $[\mathrm{Fe} / \mathrm{H}]$ was due to the metal-rich nature of planet-hosting stars, i.e. due to Galactic chemical evolution. They also found two different sloped trends for $[\mathrm{C} / \mathrm{Fe}]$ with $[\mathrm{Fe} / \mathrm{H}]>0$ and $[\mathrm{Fe} / \mathrm{H}]<0$, and a flat distribution of the $[\mathrm{C} / \mathrm{Fe}]$ ratio for all planetary masses. Recently, Pavlenko et al. (2019) have reported that metal-rich dwarfs with planets are richer in carbon with $\langle[\mathrm{C} / \mathrm{O}]\rangle=0.05 \pm 0.05$.

The magnesium to silicon ratio $[\mathbf{M g} / \mathbf{S i}]$ is higher for the stars with low-mass planets (Adibekyan et al. 2015); the correction for the NLTE effects (Adibekyan et al. 2017) has resulted in a small difference, and high $[\mathrm{Mg} / \mathrm{Si}]$ ratios in the stars hosting Super-Earth/Neptune-mass planets are likely to be associated with their formation. The correlation between $\mathbf{C} / \mathbf{O}$ and $\mathbf{M g} / \mathbf{S i}$ is crucial to the determination of mineralogy of planetary companions (Suárez-Andrés et al. 2018, HARPS sample). The authors obtained $\mathbf{C} / \mathbf{O}<0.8$ for their entire sample of planets. Among stars with high-mass companions, $0.8>\mathrm{C} / \mathrm{O}>0.4$ was reported for $86 \%$ of stars and $\mathrm{C} / \mathrm{O}<0.4$ for $14 \%$. $\mathbf{M g} / \mathrm{Si}$ is $1<\mathrm{Mg} / \mathrm{Si}<2$ for all the stars with low-mass planets and $85 \%$ of those with high-mass companions, and $\mathrm{Mg} / \mathrm{Si}<1$ for the remaining $15 \%$ of the last ones. There were no planet-hosting stars with $\mathrm{Mg} / \mathrm{Si}>2$. For planethosting stars with low-mass companions, $\mathrm{C} / \mathrm{O}$ and $\mathrm{Mg} / \mathrm{Si}$ were similar to the solar ones, whereas $\mathrm{C} / \mathrm{O}$ was lower for the stars with high-mass companions.

A correlation between the abundance differences and condensation temperature $\mathbf{T}_{\text {cond }}$ may also be indicative of the presence of Earth-like planets. Melendez et al. (2009) revealed that the Sun exhibited a depletion of refractory elements relative to the volatile ones as compared to the solar twins. The finding was associated with the formation of planetary systems like our own one, in particular with the existence of terrestrial planets (Melendez et al. 2009). Further, it was shown that similar relationships might reflect a wide diversity of exoplanetary systems observed so far, as well as a variety of scenarios which could occur for the matter in circumstellar discs (Spina et al. 2016), and that the obtained dependence of the abundance differences on $\mathrm{T}_{\text {cond }}$ was correlated with the age and birth place in the Galaxy (González Hernández et al. 2013; Adibekyan et al. 2014, 2015; Nissen 2015) being not related to the presence of planets.

The manganese abundance differences for the stars with and without planets were determined: $[\mathbf{M n} / \mathbf{F e}]$ ratios of planet-hosting stars were higher (Kang et al. 2011). As regards the neutron-capture elements: low barium content was found in planet-hosting stars (Mishenina et al. 2015); and Delgado Mena et al. (2018) reported Ba, Sr, $\mathrm{Ce}$ and $\mathrm{Zr}$ underabundances in the stars with planets, with the only statistically significant $(3 \sigma)$ underabundance of 0.03 dex being observed for $\mathrm{Ba}$ in low-mass planet hosts.
This study is aimed at independent assessment of the relationship between the presence of massive planets and specific features of chemical composition of parent stars.

\section{Observational data}

We used the stellar spectra from the OHP archive (Moultaka et al. 2004) of the echelle-type spectrograph SOPHIE (Perrushot et al. 2011) obtained at $\mathrm{R}=75,000$ in the wavelength range 4,400-6,800 $\AA$ and signal-to-noise ratio $(\mathrm{S} / \mathrm{N})$ better than 80 . The spectra processing was performed using the DECH20 software package developed by G.A. Galazutdinov (2007), http://gazinur.com/DECH-software.html.

Planet-hosting stars with detected massive planets (with the planetary masses $\mathrm{M}_{\mathrm{pl}}$ greater than the mass of Jupiter M_J), as well as stellar and planetary characteristics, were adopted from the following sources: Moutou et al. (2014) for HD13908; Herbrar et al. (2016) for HD143105, HD35859, HD220842, HD12484, HD141399, HIP65407 and HD109384; Diaz et al. (2016) for HD191806 and HD221586; Santos et al. (2016) for HD219828 and Rey et al. (2017) for HD17674 and HD290213.

\section{Determination of parameters and chemical compositions}

The effective temperatures $\mathbf{T}_{\text {eff }}$ were derived by the calibration of the line-depth ratios for spectral-line pairs with different low-level excitation potentials (Kovtyukh et al. 2003), under the condition of independence of the $\mathrm{Fe}$ content along the Fe I lines on the low-level potential of the relevant line. The surface gravities log $g$ were computed by the ionisation balance; the microturbulent velocity $\mathrm{V}_{\mathrm{t}}$ was determined by factoring out the correlation between the abundances and equivalent widths of the Fe I lines. We used the Fe I lines to derive $[\mathrm{Fe} / \mathrm{H}]$.

The elemental abundances were determined using Castelli \& Kurucz (LTE) models. The Kurucz WIDTH9 code was used for the LTE determination of $\mathrm{Na}, \mathrm{Mg}, \mathrm{Al}$, $\mathrm{S}, \mathrm{Si}, \mathrm{K}, \mathrm{Ca}, \mathrm{Sc}, \mathrm{Ti}, \mathrm{V}, \mathrm{Cr}, \mathrm{Mn}, \mathrm{Fe}, \mathrm{Co}, \mathrm{Ni}, \mathrm{Zn}, \mathrm{Y}, \mathrm{Zr}, \mathrm{Ba}$, $\mathrm{La}, \mathrm{Ce}, \mathrm{Pr}, \mathrm{Nd}$ and $\mathrm{Sm}$ abundances. The modified latest version of STARSP (Tsymbal, 1996) was employed for the LTE determination of $\mathrm{Li}, \mathrm{C}, \mathrm{O}$ and $\mathrm{Eu}$ abundances. The total uncertainty due to parameter and EW errors for the Fe I and Fe II lines are 0.06 and 0.08, respectively. The determination accuracy varies from 0.06 to $0.12 \mathrm{dex}$ for different elements.

The comparison of the synthetic and observed spectra for the CI $5380 \AA$ line for HD 17674 is presented in Fig. 1.

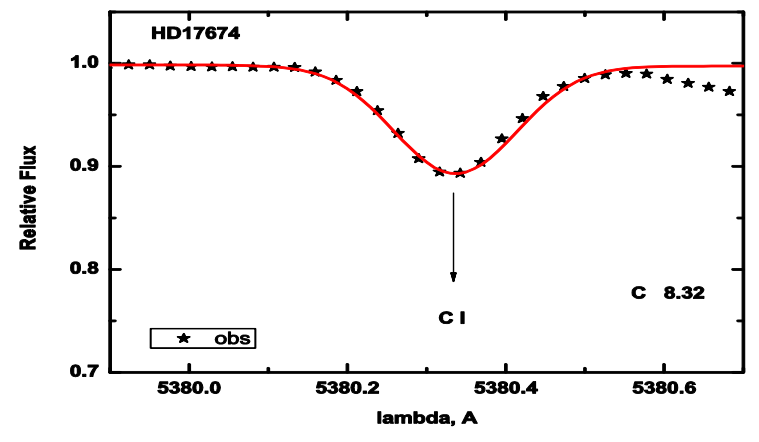

Figure 1: The observed (asterisks) and calculated (solid line) spectra in the region of the C I line for HD 17674. 


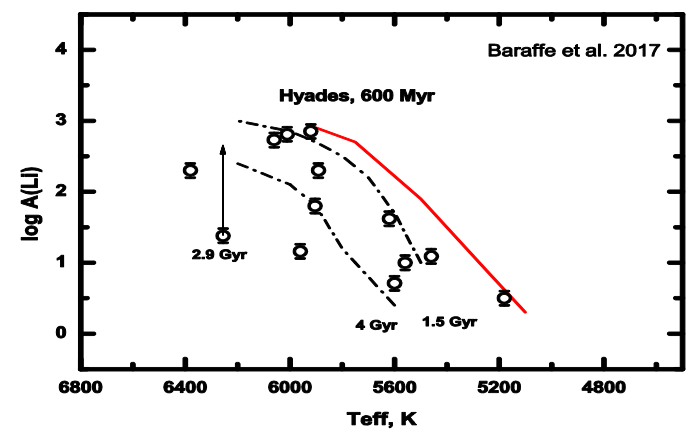

Figure 2: Li abundance vs. Teff

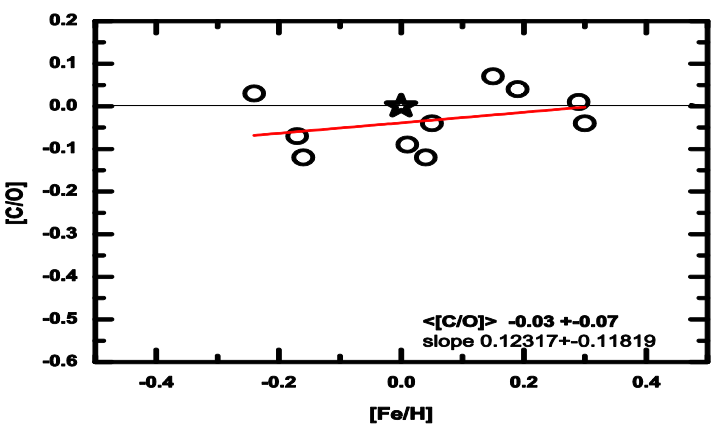

Figure 3: $[\mathrm{C} / \mathrm{O}]$ vs. $[\mathrm{Fe} / \mathrm{H}]$

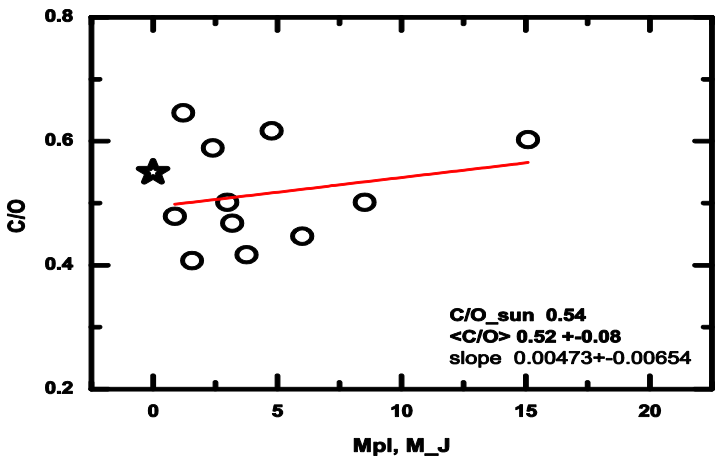

Figure 4: $[\mathrm{C} / \mathrm{O}]$ vs. planetary mass $\mathrm{M}_{\mathrm{pl}}$

\section{Results and discussion}

As follows from the Introduction, there are some potential chemical indicators of the presence of planets of different masses $([\mathrm{Fe} / \mathrm{H}], \mathrm{Li}$ abundance, $\mathrm{C} / \mathrm{O}, \mathrm{Mg} / \mathrm{Si}$ etc $)$.

Metallicity $[\mathbf{F e} / \mathbf{H}]$. Our target stars with massive planets differ in metallicity $-0.3<[\mathrm{Fe} / \mathrm{H}]<0.4$. Therefore, the supermetallicity cannot be the only reliable criterion of the presence of planets.

Li abundance. Fig.2 illustrates the correlation between the $\mathrm{Li}$ abundance $\log \mathrm{A}(\mathrm{Li})$ and $\mathrm{T}_{\text {eff. The evolutionary }}$ tracks taken from Baraffe et al. (2017) are marked with dash-dotted lines for different ages.

As can be seen in Fig.2, different Li abundances in our target stars correspond to the evolutionary changes. Only one star (HD13908) with the age of 2.9 Gyr exhibits the Li depletion as compared to the evolution predictions. The star HD13105 (with $\log \mathrm{A}(\mathrm{Li})=1.16$ and rotational velocity $v_{\sin } i=8.1 \mathrm{~km} / \mathrm{sec}$ ) enables to suppose that rotationally induced mixing rather than the presence of planets might be responsible for greater depletion of $\mathrm{Li}$ as

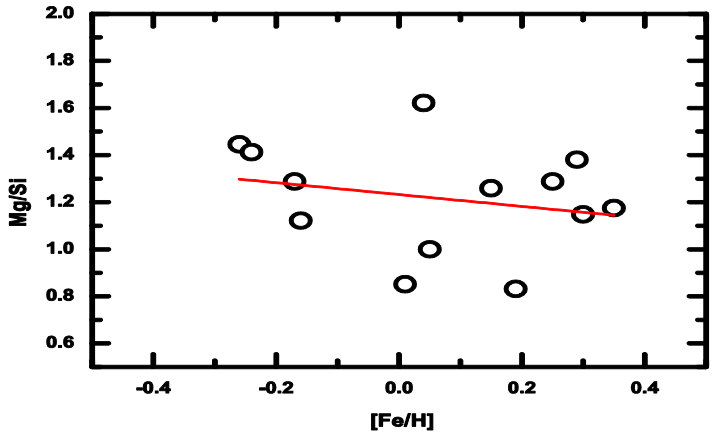

Figure 5: $\mathrm{Mg} / \mathrm{Si}$ vs. $[\mathrm{Fe} / \mathrm{H}]$

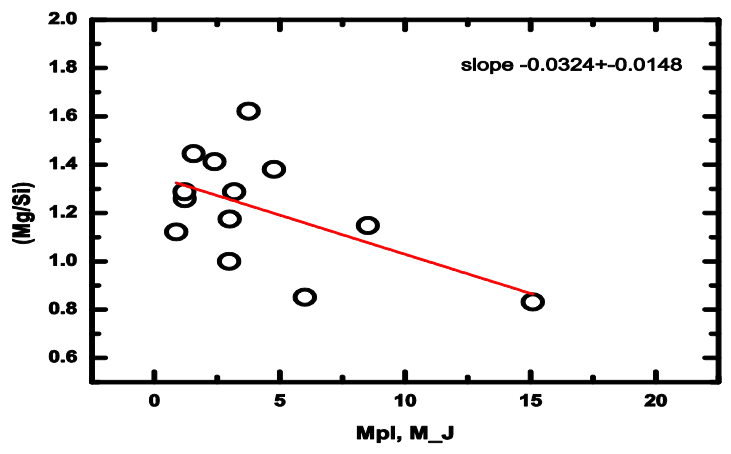

Figure 6: $[\mathrm{Mg} / \mathrm{Si}]$ vs. planetary mass $\mathrm{M}_{\mathrm{pl}}$

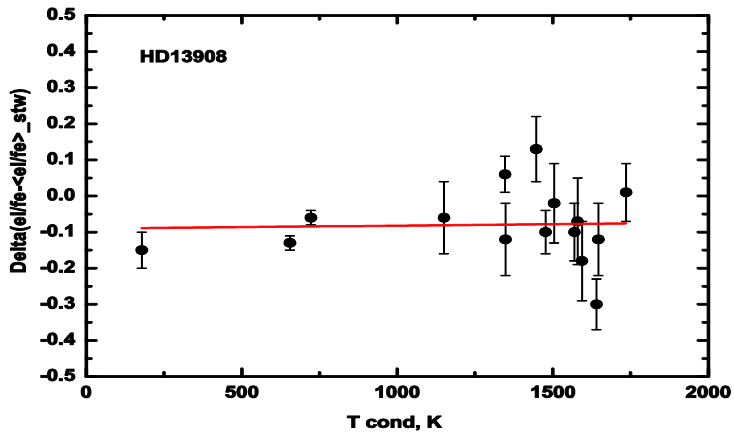

Figure 7: Relationship between the relative elemental abundances and $\mathrm{T}_{\text {cond }}$ for the star HD13908.

suggested by Delgado Mena et al. (2015). The separately considered low estimates of the lithium abundance with no thorough analysis of the potential causes of its depletion cannot be reckoned as a reliable criterion of the presence of massive planets either.

$\mathrm{C} / \mathrm{O}$ and $[\mathrm{C} / \mathrm{O}]$ ratios. Figs. 3 and 4 show $[\mathrm{C} / \mathrm{O}]$ vs. $[\mathrm{Fe} / \mathrm{H}]$ and $\mathrm{C} / \mathrm{O}$ vs. $\mathrm{M}_{\mathrm{pl}}$. Our average values $[\mathrm{C} / \mathrm{O}]=-0.03$ \pm 0.07 and $\mathrm{C} / \mathrm{O}=0.52 \pm 0.06$ do not support carbon enrichment in our target sample of stars, though they are consistent with the results obtained with HARPS spectrograph by Suarez-Anders et al.(2018): $0.8>\mathrm{C} / \mathrm{O}>$ 0.4 for $86 \%$ of high-mass companions and $\mathrm{C} / \mathrm{O}<0.4$ for the remaining $14 \%$. However, we observe a slight trend of $\mathrm{C} / \mathrm{O}$ with metallicity and planetary mass.

$[\mathbf{M g} / \mathbf{S i}]$ ratio. The observed trend of $[\mathrm{Mg} / \mathrm{Si}]$ with metallicity (Fig. 5) can be due to the Galactic evolution; the average $\langle[\mathrm{Mg} / \mathrm{Si}]\rangle_{\mathrm{pl}}=-0.05 \pm 0.09$ is lower than the solar value of $[\mathrm{Mg} / \mathrm{Si}] \odot=0.0$. We can also see the scatter of $[\mathrm{Mg} / \mathrm{Si}]$ in the region of several Jupiter masses, as well as correlation between $[\mathrm{Mg} / \mathrm{Si}]$ and $\mathrm{Mpl}$ with lower values corresponding to greater masses (Fig. 6). 
Relative abundance of refractory elements to volatile ones. For all our target stars, we plotted the relationship between the relative abundance of refractory elements to volatile ones and condensation temperature $\mathrm{T}_{\text {cond }}$ (Fig. 7).

For none of the stars did we find any significant sloped trends (correlations).

$[\mathbf{M n} / \mathbf{F e}] .[\mathrm{Mn} / \mathrm{Fe}]$ ratios in planet-hosting stars are higher (Kang et al. 2011). Our average value is $<[\mathrm{Mn} / \mathrm{Fe}]\rangle=0.10 \pm 0.06$.

Neutron-capture elements: with low $\mathrm{Ba}$ in the stars hosting low-mass planets (-0.03, Delgado Mena et al. 2015), we obtained $\langle[\mathrm{Ba} / \mathrm{Fe}]\rangle=0.09 \pm 0.16$ for the stars with massive planets.

\section{Conclusions}

For the target set of stars with massive planets, we have found metallicities ranging from -0.3 to 0.4 ; there is the only star in the sample for which the lithium content has been reliably shown to be lower as compared to the stellar evolution predictions; the average $\langle\mathbf{C} / \mathbf{O}\rangle$ ratio $=$ $0.52 \pm 0.08$ is slightly lower than the solar one $(0.54)$ while $\mathrm{C} / \mathrm{O}$ ratios tend to be dependent on the planetary mass; magnesium follows the trend in Galactic chemical evolution exhibiting a dependence on the planetary mass.

Our determinations of the $\mathrm{C} / \mathrm{O}$ and $\mathrm{Mg} / \mathrm{Si}$ ratios are in good agreement with the results of Suárez-Andrés et al. (2018). Manganese and barium are slightly overabundant. For none of the studied stars did we find any significant correlation (sloped trends) between the relative abundances of refractory elements to volatile ones and condensation temperatures $\mathrm{T}_{\text {cond. In summary, }}$ we cannot reliably single out one or another criterion. A larger sample of stars is required to ensure the determination and further application of statistically significant criteria.

\section{References}

Adibekyan V. Z., Delgado Mena E., Sousa S. G. et al.: 2012a, $A \& A, \mathbf{5 4 7}, 36$.

Adibekyan V. Z., Sousa S. G., Santos N. C. et al.: 2012b, $A \& A, \mathbf{5 4 5}, 32$.

Adibekyan V., Santos N.C., Figueira P. et al., 2015, A\&A, 581, L2.

Adibekyan, V., Goncalves da Silva, H. M. Sousa, S. G. et al.: 2017, Ap, .60, 325A.

Baraffe I., Pratt J., Goffrey T. at al., 2017, ApJL, 845, 6B.

Baumann P., Ramirez I., Melendez J.et al.: 2010, $A \& A$, 519, 87.

Delgado Mena E., Israelian G., González Hernández J. I. et al.: 2014, $A \& A, \mathbf{5 6 2}, 92$.

Delgado Mena E., Bertrán de Lis S., Adibekyan V.Zh. et al.: 2015, $A \& A, \mathbf{5 7 6}, 69$.

Delgado Mena E., Adibekyan V., Figueira P. et al.: 2018, PASP 130094202.

Diaz e R.F., Rey J., Demangeon O. et al.: 2016, $A \& A$, 591, 146.

Carlos M., Nissen P., Melendez J.: 2016, A\&A, 587, id. A100.
Castelli F., Kurucz R. L.: 2004, ArXiv Astrophysics eprints, astro-ph/0405087.

Figueira P., Faria J. P., Delgado-Mena E. et al.: 2014, $A \& A, \mathbf{5 7 0}, 21$.

Fischer D. A., Valenti J.: 2005, ApJ, 622, 1102.

Gaidos E.: 2015, ApJ, 804, 40.

Gonzarlez Hernarndez J. I., Delgado-Mena E., Sousa S. et al.: 2013, A\&A, 552, 6.

Gonzalez G.: 1997, MNRAS, 285, 403.

Gonzalez G., Laws C.: 2000, AJ, 119, 390.

Gonzalez G.: 2008, MNRAS, 386, 928.

Gonzalez G., Carlson M. K., Tobin R. W.: 2010, MNRAS, 407, 314.

Herbrar G., Arnold L., Forveille T.et al.: 2016, A\&A, 588, A145.

Israelian G., Santos N. C., Mayor M., Rebolo R.: 2001, Nature, 411, 163.

Israelian G., Santos N. C., Mayor M., Rebolo R.: 2004, $A \& A, \mathbf{4 1 4}, 601$.

Israelian G., Delgado Mena E., Santos N. C et al.: 2009, Nature, 462, 189.

Kovtyukh V. V., Soubiran C., Belik S. I., Gorlova N. I.: 2003, A\&A, 411, 559.

Kuchner M.J. \& Seager S.; 2005, arXiv:astro$\mathrm{ph} / 0504214 \mathrm{v} 2$.

Melendez J., Asplund M., Gustafsson B., Yong D.: 2009, ApJ, 704, L66.

Mishenina T, Kovtyukh, V., Soubiran C., Adibekyan V. Zh.: :2015, MNRAS, 462, 1563.

Montalban J., Rebolo R.: 2002, A\&A, 386, 1039.

Moultaka J., Ilovaisky S., Prugniel Ph., Soubiran C.: 2004, PASP, 116, 693.

Moutou C., Hébrard G., Bouchy F.et al.: 2014, A\&A, 563, A22.

Nissen P.E.: 2013, A\&A, 552 A73.

Nissen P.E., Chen Y. Q., Carigi, L. et al.: 2014, A\&A, 588, 25.

Onehag A., Gustafsson B., Korn A.: 2014, A\&A, 562, 102.

Pavlenko Y. V., Kaminsky B.M., Jenkins J.S.et al.: 2019,

$A \& A, 621$, id.A112.

Perruchot, S., Bouchy, F., Chazelas, B. et al.: 2011, in Proc. SPIE, 8151, 37.

Petigura E., Marcy G.: 2011, ApJ, 735, 41.

Rey J., Hébrard G., Bouchy F. et al.: 2017, A\&A, 601, 9.

Santos N. C., Israelian G., Mayor M.: 2001, $A \& A, 373,1019$.

Santos N.C., Santerne A., Faria J.P. et al.: 2016, $A \& A$, $\mathbf{5 9 2}, 13$.

Sousa S.G., Santos N.C., Mayor M.. et al.: 2008, $A \& A$, 487, 373.

Spina L., Melendez J., Ramırez I.; 2016, A\&A, 585, 152.

Suárez-Andrés L., Israelian G., González Hernández J.I. et al.: 2016, $A \& A, \mathbf{5 9 1}, 69$.

Suárez-Andrés L., Israelian G., González Hernández J.I. et al. 2017, A\&A, 599, id.A96.

Suárez-Andrés L., Israelian G., González Hernández J.I. et al. 2018, $A \& A, \mathbf{6 1 4}$, id.A84.

Teske J.K., Cunha, K., Smith V.V.et al.: 2014, ApJ, 788, 39.

Tsymbal V., 1996, ASP Conf. Ser., 108, 198.

Udry S., Santos N. C.: 2007, ARA\&A, 45, 397. 